\title{
Mengamati, Mendiskusikan, dan Mempublikasikan: Penelitian dari Awal Sampai ke Penulisan
}

\author{
Ismail Suardi Wekke \\ Pusat Studi Kepemimpinan Transformatif \\ Pascasarjana Institut Agama Islam Negeri (IAIN) Sorong \\ Email: iswekke@gmail.com
}

Selamat Anda sudah menyelesaikan proposal tesis. Langkah yang sangat bagus, dan perlu diapresiasi atas kerja saudara.

Penelitian ini sangat kontekstual, Februari mendatang insya Allah muktamar DDI. Kemudian DDI juga sudah menuju satu abad.

Bedakan bahasa media sosial dengan bahasa tesis (penulisan akademik).

Referensi sangat bagus, sudah menggunakan jurnal.

Apa sumber data?

Bagaimana triangulasi?

Dua pertanyaan ini perlu diperhatikan.

Tipologi penelitian? Perlu dipertegas. Kalau pakai kualitatif, lalu kualitatif yang mana? Bukan kualitatif deskriptif.

Ribuan? Pakai data. Kalau hanya sebuah ceramah, maka pakai opini. Tapi lebih pada data. Bukan rasa-rasanya, tetapi data-datanya.

kata "transfomasi", dalam kaitan dengan Gurutta Ambo Dalle, itu apakah tranformasi? Sebab beliau pendiri.

Silahkan baca juga disertasi Prof. Bahaking Rama.

Ini penelitian sejarah? Sebab saya lihat ada batasan tahun.

Rumusan masalah justru bermasalah. Pakai bahasa Inggris yang justru saya tiak bisa mengerti.

Sementara itu, manfaatnya terlalu besar karena menjadi inspirasi. Silahkan fokus pada penelitian saja. Soal manfaat yang tidak bisa diukur, tidak perlu dibahas.

Referensi, selalu saya katakan. Verifikasi dan juga bedakan antara referensi dan data. Kalau YouTube? Bukan referensi. Pengayaan boleh, tetapi bukan sumber utama.

Tadi, disampaikan ada pelbagai aspek. SDM, kurikulum, semua yang berkembang. Itu merupakan penelitian yang luas. Sementara penelitian perlu fokus.

Terakhir, baca lagi buku Noeng Muhadjir. Untuk supaya lebih terarah. Buku ini menjelaskan secara detail terkait penelitian kualitatif. 


\section{Daftar Pustaka}

Wekke, I. S. (2013). Tinjauan Mohammad Arkoun tentang Bahasa Arab, Teks dan Semiotika AlQur'an. Jurnal Ushuluddin: Media Dialog Pemikiran Islam, 17(1), 64-80.

Wekke, I. S. (2014). Kitab Suci, Bahasa Arab dan Pembacaan Teks: Tinjauan Filsafat Mohammed Arkoun. Ulumuna, 18(2), 243-268.

Wekke, I. S., \& Busri, M. (2016). Kepemimpinan Transformatif Pendidikan Islam: Gontor, Kemodernan, dan Pembelajaran Bahasa. Yogyakarta: Deepublish.

Wekke, I. S., Rubawati, E., \& Nurjannah, S. (2017). Kepemimpinan Transformatif di Madrasah Minoritas Muslim Papua Barat. J-MPI (Jurnal Manajemen Pendidikan Islam), 2(1), 1-10.

Wekke, I. S., Siarni, S., \& Nuryantika, N. (2016). Kepemimpinan Sekolah Islam Terpadu di Minoritas Muslim Papua Barat. Akademika: Jurnal Keagamaan Dan Pendidikan, 12(2), 3 9.

Wekke, I. S., Wihayuningtyas, N., Muntaha, P. Z., \& Mukhlis, M. (2018). Leadership Typology of Traditional Islamic Boarding School in Eastern Indonesia: Learning to Lead from DDI Mangkoso. INFERENSI: Jurnal Penelitian Sosial Keagamaan, 12(2), 331-348.

Wihayuningtyas, N., Amin, S., \& Wekke, I. S. (2021). Kepemimpinan dalam Memperjuangkan Pendidikan Bagi Minoritas Muslim Papua. Yogyakarta: Bintang Pustaka Madani. 